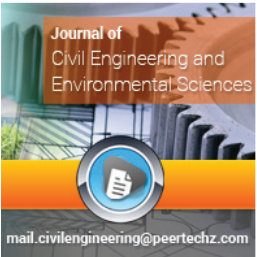

\title{
Journal of Civil Engineering and Environmental Sciences
}

\section{Najeeb Utmani ${ }^{1 *}$, Shiraz Ahmad ${ }^{2}$, Riaz} Ul Islam ${ }^{3}$ and Muhammad Abbas ${ }^{4}$

IID: 11367, MS (CEM) INU, Pakistan

${ }^{2}$ Lecturer INU Peshawar, Pakistan

${ }^{3}$ Project Engineer IRSP Islamabad, Pakistan

${ }^{4} R E$ in SAK Consultant, Pakistan

Received: 19 December, 2018

Accepted: 09 January, 2019

Published: 10 January, 2019

*Corresponding author: Najeeb Utmani, ID: 11367, MS (CEM) INU, Pakistan, E-mail: najeebcem6@gmail.com

Keywords: Gabion structure; Retaining wall; Abutment; Implementation; Lateral movement; Land sliding; Erosion and scouring; Effectiveness; Resisting; Settlement; Environmental

https://www.peertechz.com

\section{Check for updates}

\section{Literature Review \\ Gabion wall used in road construction and flood protection embankment}

\section{Abstract}

The scope of this paper is related to study of the gabion wall as retaining structure as well as load bearing member in hilly areas by considering various engineering factors such as structural stability, flexibility, aesthetics exposure and economic serviceability by following the design parameters such as overturning moment, sliding resistant and bearing pressure. Nowadays new construction methodologies as well design by various software's come into existent to make it easy the implementation of structure practically but due to adverse effects of climate changes, the concept of gabion wall retaining structure plays vital role for road construction in hilly areas as well as in flooding areas on the river banks. Its common in the recent days that structural member perform multiple duties for given project, but the concept of gabion retaining wall perform such type of needs. Gabion wall also control the erosion and scouring of land in flood protection embankment in the form of retaining structure, e.g. Gi wire retaining wall with various steps along with apron which provides launching and siltation after a period of time or high flooding. Such type of gabion retaining wall is used in KP province of Pakistan after high flood disaster occurred in 2010 on River Kabul District Nowshera.

Objective of the study: The main objective of gabion walls is to control land sliding on road sides, erosion and scouring on the rivers banks during flood and high velocity river streams and prevent the water logged areas from further damaging. They also support the moment of the soil and rock laterally in hilly areas by providing the function of breast walls. Our main goal is to enlighten the gabion wall as retaining structure as well load bearing member by determining its dual behaves in order to provide the strength, efficiency and structural stability by decreasing the total estimating cost while retaining the aesthetics needs and following the actual design and routine supervision.

The paper also focuses on determining the conditions and implementing of gabions walls in bridge abutments and culverts and pier for elevated flyovers which are acting as breast walls by evaluating the parameters of overturning movement, resisting movement, sliding resistant and load bearing force.

\section{Introduction}

Gabion are wire-stone element in the shape of hexagonal or cuboids made of wire mesh with double or triple twisting, filled with local stone or quarry using for retaining wall, sea walls, mechanically stabalized earth MSE walls, hydraulic works and channels lining or revetments. The primary purpose of gabion retaining wall is to provide lateral movement of soil or rock in order to control the active earth pressure and also resist the transverse load in case of gravity retaining wall which are settled and stabilized by their weight. Gabion walls are GI wire mesh tested by laboratory to verify their galvanizing and gauge properties having hexagonal and certainly may be rectangular in structure with double or triple twisting should be given in order to enhance strength property. The wire mesh containers or mattresses are properly filled by local boulders or stones approved from different quarries sources depending upon the size and shape. They are placed upon each other and tied securely in order to form monolithic massive structure for low height gravity walls. The stability is achieved by their self weight and reunion by the apron which is spread widely in the form of rectangular crates having proposed dimensions. The gabion mesh boxes or crates provide stability and rigidity to the structure on the backfill. The GI wire mesh also superimpose reinforcement to the structure which gives additional stability, these type of structure is called earth reinforcement retaining wall.

Gabion retaining wall occupy good ratio with respect to cost and effectiveness and also have low environmental impact conditions because the ease of placement, casting is easy to be handle and foundations work can easily carry out and somehow good aesthetics.

\section{Literature Review}

\section{Gabion wall protects landslides and river training works} by [1]

The applications and significance of flexible gabion wall 
for landslides incase of road construction and river training works was explored by Ferriolo $\mathrm{F}$ in the year 1997. The gabion mattresses or crates plays vital role in flooding areas as well as in land sliding areas due to its flexibility property. The scope of study in this paper is to use gabion structures in road construction due to its stability and control erosion and scouring by its main characteristics such as high resisting weight and permeability. The resisting property is usually control by the gathering effect of hexagonal wire mesh and stone filling. The soil under road and backfilling or landslides incase of breast wall is supported by gabion wire mesh. Authors also mentioned the internal details of various properties such as diameter of wire gauge, galvanizing extent, mesh size and opening, double or triple twisting, hexagonal shape etc also plays important role during implementing gabion structure.

\section{The stability of Gravity retaining structure by [2]}

Ivan Nesovic paper investigates the probable characteristics of gabion retaining structure for those freezing and snow fall areas, where landslides occurrence is high due to which soils and obstructions occurs in roads sides, so in these cases the implementation of gabion retaining structure is widely spread by which road ways and routes again brought into original state to efficient and effective way. To avoid such hurdles of transportation, large gabion walls having several rows and steps filled with several crush stones and boulders are implemented in order to avoid big consolidation of landslides. For this purpose large gabion wall having five setback rows were originated in the city of Alekinsac to control land sliding performing its duty on huge weight.

\section{Design of gabion - Geosynthetic Retaining walls in $\mathrm{Ca}$ - lifornia by $[3,7]$}

The design and construction of mechanically stabilized earth MSE walls on the city of Robbinsville highway was elucidated by Simac MR Bathurst (1997). The components of wall were constructed in hybrid system which consists of geogrid reinforcement and PVC coated gabion baskets. These materials and ingredients were primarily based on the presence of chemicals active environment and were available from the local queries which fulfill cost and aesthetics appearance. This paper also incorporates the design of wall which ensures stability along with proper alignment of mountainous highway and also observed the guidelines of MSE design as presented in the project specifications, which were overstated with current approved methods of analysis to provide safe and economical wall design. The paper also explains the laboratory tests which were held out to ensure that the connections between baskets or crates and reinforcement were sufficient.

\section{Stabilization of slope for Hill road - Indian Geotechnical Conference 2010 by}

Indian Geotechnical Conference - 2010, Geotrendz December 16-18, 2010 IGS Mumbai

\section{Chapter \& IIT Bombay}

The case study of this paper delivers a slope failure and remedies for their measurements in Chora Ghat highway. The retained slope $4.3 \mathrm{~m}$ gravity wall along with $20 \mathrm{~m}$ high steep given to the highway from one side and narrow deep valley town on the other side but in this paper we are suggesting two alternatives in order to control the slope failure during heavy rain falls. These may include by providing gentle slope of 15 degree with pitching of $3 \mathrm{~m}$ from top of existing retaining wall and then provided gabion wall of RCC for the remaining height as were left during pitching, this may drain out the infiltrated water which can be restored in the base of gabion wall. The second option is to build a reinforced wall using geocomposites which consists of wire mesh. The author is also suggested MSE gabion wall for the local site conditions and topography. These types of gabion wall are highly permeable and flexible which can control the water pressure very strongly and can resist the differential settlement and lateral movement. The cost consumption is very effective and trustworthy due to its availability of local fill materials, also consuming short time during construction and permits to growth of vegetation and behaves as eco-friendly.

\section{Control of erosion and scouring through spurs/groynes: by [8]}

Spurs or groynes are transverse structures at an angle to the flow of water from the bank which may usually diverts or reduce the velocity of flow by producing siltation. Spurs may be pervious or impervious structures. The removal of soil particle by flowing water is term as erosion. It may be general erosion and local scour, which may involves the removal of exposed particles from the extensive land, stream bank or surfaces and local scour is the removal of single particle from the base of river, these may be controlled by using various types of gabion spurs i.e. repelling spurs, attracting spurs and deflecting groynes, performing their function for cohesive materials and non-cohesive materials. The design of spurs or groynes includes the fixation of top width, free board, side slopes, and size of stones for gabion and pitching, filter and launching apron.

Rock filled gabion treatment for erosion control: by $[9,10]$

According to given paper of Daniel which observes the effectiveness of Rock filled gabion along with Rip-Rap and culverts treatment for erosion control during post-fire erosion mitigation in 2010 monsoon, Schultz fire. Other treatments such as removal of culvert at elevation in the forest of northcentral Arizona were implemented along with sixteen rockfilled wire gabion cages in channel crossing to reduce the incision of erosion in alluvial sediments. The rock gabions were placed in equal distance in ditch. The individual gabion cages were about $60 \times 60$ in cross section and 2 to $3 \mathrm{~m}$ long, the drainage was constructed in straight fall line with gradient of $4 \%$. The lines were buried in soil on both sides of ditches while the wing walls of gabion were not properly crossing the ditches slope.

\section{Failure of gabion structure by model test: by}

Der-Guey Lin, Bor-shun Haung, Shin-Hewi Lin

Peryas et al in 1992 proposed a scale model test of stepped 
gabion spillways introducing into different type of loads. The test represented the prediction of flood in excess of $1.5 \mathrm{~m}^{3} /$ $\mathrm{sec} / \mathrm{m}$. the opening of mesh should be binded tightly where gabion spillways can hold flows up to $3 \mathrm{~m}^{3} / \mathrm{sec} / \mathrm{m}$ without excessive failure. The test also disclose some deformation of gabion due to inside movement of stone filling. For this reason some suggestion wesre given by Les ouvrages en gabions (1992) on avoiding gabion deformation. He examines the stone quality and packing at the top layers of gabion courses, as the stone size were 1.5 times larger than the usual.

\section{Gabion control Erosion along sheltered shorelines: by}

Andrew J. Rella, \& Jon K. Miller, Ph.D. Hudson River Valley Greenway,Hudson River National Estuarine. Research Reserve

Gabion are frequently separated into gabion baskets, gabion mattresses and sack gabion which are filled with cobbles or crush rock and then stacked with each other to form a permeable, flexible and gigantic structure. Gabion mattresses and baskets are usually similar structures that were illustrious by thickness and height which control eroding beds and banks while gabion baskets are taller structures with more reliability of height 1 to $3 \mathrm{ft}$. gabion sacks are less commonly used consist of mesh sacks filled with rocks or sand. They are placed with each other vertically forming a stacked structure which is more suspectable to failure and when placed along slope, they form revetment. Gabions are premeditated with several primary design considerations by including the stability of foundation, the shear-stress resistance of structure and toe-flank of structure

\section{Methodology}

The design of all type gabion walls is structuralized by various complete integrated software's which fulfills all the feasible requirements such as economic, aesthetics and ecological factors. these latest software's should follow all the comprehensive figures, visualization, Schematic drawings and all design requirements that can easily understands the users who can analyze the design results and implementation practically. The installation of gabion wall is carryout by contractor practically in the presence of Engineer who verifies all the installation procedure and following all the designing parameters i.e. overturning, sliding and bearing soil pressure elucidated in case study by figure.

\section{Analysis}

During installation of gabion practically or by software's the required data such as loading conditions, surcharge, hydrostatic pressure, slope and density of backfill, density of gabion fill materials, galvanizing value of gabion and zinc coating should be carryout while designing, these all values should be added on the software's and find out the stability and all required necessary parameters. These all values should be checked primarily against overturning and sliding and allowable soil pressure. These all parameters should be changed regularly if the failure is examined.

\section{Advantages}

Gabion retaining wall plays important role in construction of roads, flood controlling works, canal linings and hydraulic works. They are out most important due to its cost effectiveness, ecological aspect, durable and less time consuming during construction, economical and eco-friendly, by resisting these factors gabion have the following advantages.

- Gabion should be easily repaired any damaged section or baskets with less expenses.

- They have very low cost and perfect for all type of soil and climate conditions.

- They can easily be executed and handle during construction

- They have no need of curing and shuttering as were needed for other structures.

- Their work construction is not interrupted by heavy rainfall and water shortage.

- They are eco-friendly and aesthetics appearances.

- Gabion structure control noise pollution due to its high stability and density.

- They can acts as vibration absorbers near railway tracks.

They can survive life for years after rusting of gabion as they resist corrosion.

\section{Future considerations}

Gabion retaining wall should be design for road construction and flooding embankments on the mentioned standard parameters as were studied in the case study, because they have vital future planning to execution for its stability and environmental impact conditions and also at climate variations, as they have cost effective, durable and flexible due to the following considerations.

- Gabion wall should be design with standard parameters as overturning or settlement usually occurs on top step.

- The geotechnical investigations should be carry out properly while designing for loose soil and slush as the failure of structure occurs after period of time.

- The Gi wire mesh opening should be checked properly at every stage as the contractor avoids such supervision to save their money.

- The twisting should be checked properly either double or triple on the site.

- The various laboratory tests of GI wire and stones should be held regularly before starting the work on site.

- The faced looking stones should be placed in front of gabion as the aesthetic appearance shall be visible. 
- The alignment should be followed properly as were held on the survey before the implementation.

\section{Labaratory tests and results}

In this paper various tests on gabion wire mesh and stones filled materials shall performed on the approved laboratories such as Pakistan Council of Scientific and Industrial Research (PCSIR) and University of Engineering \& Technology Peshawar (UET) soil mechanics lab. During a site supervision on flood Embankment some data and results were collected practically. The results for these tests were conducted on the project of River Kabul district Nowshera kpk Pakistan.

\section{Tests of stone and gi wire}

\begin{tabular}{|c|c|c|}
\hline & Parameters & Results \\
\hline 1 & Compressive strength ( $\mathrm{psi})$ & 9198.38 \\
\hline 2 & Water Absorption (\%) & 4.00 \\
\hline 3 & Dia of zinc coated wire (mm) & 04.32 \\
\hline 4 & Dia of stripped wire (mm) & 04.18 \\
\hline 5 & Weight of zinc coating (g/m2) & 400.50 \\
\hline 6 & Standard wire gauge SWG & 8 \\
\hline 7 & Tensile Strength (kg/mm2) & 39.26 \\
\hline 8 & Elongation (\%) & 17 \\
\hline
\end{tabular}

\section{Conclusion}

The technical annotations of this paper emerges from social perspective which are trended and applying on road construction, flooding structures also in bridge failures and abutments that how they control land sliding and erosion. Varies gabion diversions such as spurs or Rip-Rap structures which may control erosion by performing its basic functions while maintaining the pervious and impervious ability. The paper also examines the hexagonal design with interlocking properties compares with rectangular design which resist the lateral deformation. The decorative appearance of gabion structure also arises the environmental impact, that there is lack of wastes usually found near gabion structure. The stability of gabion structure due to their self weight is usually adopting as permanent structure. The apron part of gabion retaining wall which spreads on the lands behaves as natural land as they are cover by siltation. The backfill material should be used from the approved source and having proper drainage properties to prevent the hydrostatic pressure which cause settlement of the structure. It is also determines from case study that round stones size should cause deformation of gabion which produces movement insides the gabion cages as it were used in channel ditch. The gabion may be mattresses, baskets or sack gabion varying with height and mesh size as were stacked with each other, to form a monolithic structure. The quarry stone should be elongated and blocky rather the rounded and platy. The rock filled stone should laid properly with dressed surface to form decorated appearances. The various properties and laboratory tests of GI wire such as gauge, galvanizing and tensile strength should be carryout properly before implementing a gabion structure. It is also concluded that when there is no proper slope given, the structure would lead to catastrophe. All the soil mechanics formulas are used in every application of theory which is further derived explicitly.

\section{References}

1. Ferriolo F, Vicari M, Kulkarni TP, Gharpure AD (1997) Landslide Road Protection and River Training Works with Gabion Structures, Proceedings of Geosynthetics Asia '97, Bangalore, India. 11: 11.20. Link: https://goo.gl/tMgakZ

2. Nešović I, Paunović S, Petrović M, Ćirić N (2015) The Stability of Gravity Retaining Structures. Link: https://goo.gl/RSrMnB

3. Simac MR, Bathurst RJ, TW (1997A) Design of Gabion - Geosynthetic Retaining Walls On the Tellico Plains to Robbinsville Highway,Geosynthetics '97 Conference, California, USA. 105-118. Link: https://goo.gl/osDwgQ

4. BS 1377 (1990) Method of testing soil for civil engineering purpose. British Standard Institute, BSI ,London ,England. Link: https://goo.gl/6gXujy

5. Ramlia M, Karasu TJ, Dawood ET (2018) School of Housing Building and Planning, Universiti Sains Malaysia, Penang, Malaysia Building and Construction Technology Engineering, Technical college of Mosul, Mosul-Ira. Link: https://goo.gl/j9jm8o

6. ASTM A975-11 (2011) Standard Specification for Double-Twisted Hexagona Mesh Gabions and Revet Mattresses (Metallic-Coated Steel Wire or Metallic-Coated Steel Wire With Poly (Vinyl Chloride) (PVC) Coating). Link: https://goo.gl/bu4vom

7. CHAPTER 4 (1979) Gabion Retaining Walls. Developments in Geotechnica Engineering 27: 62-82. Link: https://goo.gl/eoG9fm

8. Peter C, Kllngeman, Scott M, Kehe, Yaw A, Owusu (1984) Department of Civil Engineering, Oregon State University. Link: https://goo.gl/p3ZzGT

9. Neary DG, Karen A, Koestner. USDA Forest Service, Rocky Mountain Research Station, 2500 Pine Knoll Drive, Flagstaff, Arizona 86001. Link: https://goo.gl/aQ1eYu

10. Hudson River Sustainable Shorelines Project.NYSDEC Hudson River National Estuarine Research Reserve.Norrie Point Environmental Center.Staatsburg, NY 12580 845-889-4745. Link: https://goo.gl/5WQnJu

Copyright: (c) 2019 Utmani N, et al. This is an open-access article distributed under the terms of the Creative Commons Attribution License, which permits unrestricted use, distribution, and reproduction in any medium, provided the original author and source are credited. 